\title{
Magical Realism in Neil Gaiman's Coraline
}

\section{Saeede Hosseinpour, Nahid Shahbazi Moghadam}

Magical realism, as a narrative mode or genre in adults' literature, has been in vogue since its revivifying with the publication of Gabriel García Márquez's One Hundred Years of Solitude (1967). However, the depiction of the genre in children's and juvenile literature is a new trend; the presence of its elements have been traced and proved feasibly applicable in the interpretation of recent children's fiction such as David Almond's Skelling (1998). In this regard, the main concern of the present article is to sift the characteristic features of magical realism within Neil Gaiman's Coraline (2002) through the application of Wendy B. Faris's theoretical framework of the genre therewith Tzvetan Todorov's definition of the fantastic in order to introduce the novel as an exemplar of magical realism in the domain of children's literature.

\section{Keywords}

Coraline; magical realism; Wendy B. Faris; Tzvetan Todorov; marvellous; matter-of-fact narration; the other mother

\section{Introduction}

Neil Gaiman has well gained a reputation both to entertain adult and child audiences by his fanciful and mostly frightening tales. Gaiman's stories, albeit full of supernatural events, are usually set in the real-life world. A prime example of such texts is his brilliant story Coraline (2002), a Hugo and Nebula award winner. The story is about Coraline Jones, a preadolescent girl whose family has recently moved to a big old house. Enamoured of exploring around and discovering new places, Coraline once enters the next-door flat and meets a fiendish creature who plans to trap her there forever. The young heroine finally manages to defeat the beldam and return home. The book has been highly well-received by critics of children's literature such as David Rudd and Karen Coats. In "An Eye for an I" (2008), Rudd takes a psychological approach and scrutinizes the text with the help of Freud's theory of the Uncanny, Lacan's the Symbolic and the Real and Kristeva's concept of the abject. He believes Coraline is "a rich and powerful work that explores areas 
seen by many as inappropriate for children" (161). According to him, the significance of the story is its involvement with the child's place in the universe (2). Coats's "Between Horror, Humour, and Hope" (2008), on the other hand, is chiefly concerned with the Gothic elements depicted in Gaiman's fiction, particularly in Coraline, suggesting that such characteristics would help the child to "cope with [...] traumas in an indirect fashion" (77). Similarly, the majority of related studies such as Michael Howarth's Under the Bed Creeping (2007), Saravia Vargas's "A Girl in the Dark with Monsters" (2014) and Emma Agnell's "When the Cat Is Away, the (M)other Will Play" peruse the novel thematically and psychologically. Taking the novel as a work of fantasy is what all the aforementioned and other related studies base their analyses on. In "The Other Mother: Neil Gaiman's Postfeminist Fairytales" (2008), Parsons, Sawers and McInally claim that the book fits into "the genre of fantasy" (1). Arguing that the novel addresses a dual readership, Richard Gooding's " Something Very Old and Very Slow': Coraline, Uncanniness, and Narrative Form" (2008) focuses on Freud's formulation of "a cultural insight into the relationship between the uncanny and fantasy literature" and suggests that Gaiman's employment of the uncanny leads readers to draw a borderline between the real and the fantastic $(3,392)$. He also points to Todorov's definition of the uncanny according to which the audience can identify a demarcation between the real world and the fantastical one. Therefore, as Gooding asserts, the supernatural happening in the story predominantly "is anticipated in a hallucinating episode occurring late at night" which departs the incidents from reality (393). With regard to the peremptory acceptance of Coraline as fantasy, the goal of this study is not to cross off the aforementioned studies but to look at this novel through a new pair of glasses. To be more specific, since no individual and full-scale generic study of Coraline exists, the present work aims to cast special attention on the novel's genre and propose that it stands under the banner of magical realism.

In order to depict magical realism in Coraline, the current study makes use of Wendy B. Faris's discussion of the genre so as to trace its elements in Gaiman's novel. In Ordinary Enchantment: Magical Realism and the Remystification of Narrative (2004), Faris enumerates and explains five qualities of the genre, the first of which deals with irreducible elements, i.e., phenomena undefinable according to accepted principles. The art of juxtaposing these inexplicable elements with the received laws of nature and quotidian life makes the audience believe "magical things 'really' do happen" in a story (8). Based on the second quality, a magical realist author meticulously portrays supernatural events and 
settings in order to strengthen the presence of the extraordinary world (Faris 14). The third feature is the moment of hesitation in accepting or rejecting the inexplicable events; hereupon, the reader undergoes perturbing doubt (Faris 17). The penultimate factor is the reconciliation between the realistic life and the supernatural realm (Faris 21). The act of merging two opposed realms in magical realist tales comes to the authors' aid to demonstrate other possible dimensions of reality. The fifth and the last characteristic is the disruption of the accepted concept of time, space and identity (Faris 23). In such novels, for instance, the past and the present may run in parallel, or a person may simultaneously be in different places. Faris's study in this realm reveals the fact that despite its complexity, akin to other literary genres, magical realism follows distinct rules. Her classification, thus, makes it possible to employ her theory not only in discussing adult fiction but also in elaborating on children's stories.

As stated before, the novel has been discussed in terms of sharing some characteristic features of fantastic literature. Nevertheless, by employing related definitions offered by Todorov in A Structural Approach to a Literary Genre (1975), it is clarified that such elements are detectable in magical realist texts as well. Therefore, Todorov's theory is propounded here in order to proclaim that, though fantasy and magical realism may have some elements in common; they are distinguishable due to the matter-of-fact manner of narration employed in the latter. The fantastic, as Todorov explains, is presented as a moment of hesitation in the face of an uncanny phenomenon which is explained "in two fashions, by types of natural causes and supernatural causes" (25). Residing at the very heart of the fantastic, hesitation may be either felt throughout to the end of the story or last only for a moment. Once the reader chooses whether to believe or reject the phenomenon, the story leaves the fantastic and enters a neighbouring genre. Todorov postulates on behalf of the reader as follows:

If he decides that the laws of reality remain intact and permit an explanation of the phenomena described, we say that the work belongs to another genre: the uncanny. If, on the contrary, he decides that new laws of nature must be entertained to account for the phenomena, we enter the genre of marvelous. (41)

In the realm of the marvellous, the irreducible features are left unexplained and accepted as real; which potentially reveals a point of commonality between 
the marvellous and magical realism. According to Todorov, "the supernatural element intervenes" in the fantastic (107); the same can be recognized in magical realism. Besides, time potentially loses its regularity and "seems suspended" in the fantastic context (Todorov 118), being presented against the laws of nature in the same vein as magical realism. Therefore, although these features are present in Coraline, the story is not subsumed under the genre of fantasy. Gooding benefits Todorov's definition of the uncanny to emphasize the fantastical nature of the novel. While acknowledging Coraline's affinity with the marvellous, the present study merges some germane parts of Todorov's theory with Faris's five qualities of magical realism to asseverate that Coraline is a magical realist novel and does not fall into the genre of fantasy. The significance of this article is to accentuate the fact that a magical realist context best furnishes Gaiman's aim in making a frightening atmosphere so palpable to a juvenile audience as to catch a glimpse of rough life situations.

\section{Collision of the Real and the Supernatural}

Gaiman begins Coraline with an epigraph from G.K. Chesterton - "Fairy tales are more than true: not because they tell us that dragons exist, but because they tell us that dragons can be beaten" (9) - as if to invite readers to believe his tale as a realistic story. Herein, Faris's five magical realist qualities - the presence of the irreducible elements, detailed description of the phenomenal world, the experience of unsettling doubts, the merging of different worlds and finally the disruption of conventional concepts of time, space and identity (7) - may best endorse this invitation.

Coraline brims with supernatural elements and its storyline portrays interplay between the realistic world and the phenomenal realm. In the quite real world of the story, the young heroine is surrounded by magic; the old actresses who can previse some upcoming events and possess a magic object and the singing mice and the wise helping cat. But, following Faris's list of the key characteristics of magical realism, the presence of the first feature is primarily epitomized by the character of the other mother. Tired of her workaholic parents who do not show the care and affection she desires, Coraline wishes to have a more exciting life. By finding the bricked door and entering the phenomenal world, it seems that her wish is granted. There, she meets the other mother, who appears to be semi-identical to Coraline's real mother: 
It sounded like her mother... she looked a little like her mother. Only... only her skin was white as paper. Only she was taller and thinner. Only her fingers were too long... and her dark-red fingernails were curved and sharp... Her eyes were big black buttons. (34)

Although the world within the next-door flat and almost everything in it is constructed by the other mother, no explanation is provided as to the nature of her origin, the beldam or the place (45). These are the questions posed by both Coraline and her readers; however, there is no answer for them or, better to say, there is no need to look for any answer because "as a given, accepted but not explained" (Faris 7), the presence of the other mother can be as equally natural as Coraline's origin is.

Another inexplicable element in the story that reinforces the bond of two paradoxical realms is the spirits of three children imprisoned by the other mother. The same as is the case with adult fiction like Toni Morrison's Beloved (1987), in which the ghost of the murdered baby haunts the house; Gaiman's novel deploys the theme and introduces some child ghosts to young readers. So, as one of the characteristics of the magical realist narration, the depiction of the supernatural in a matter-of-fact manner makes both the heroine and the readership accept the existence of the ghosts without being filled with astonishment:

Her hand touched something that felt for all the world like somebody's cheek and lips...a voice whispered in her ear...'who are you?' whispered Coraline... [the other mother] took our lives away, and she left us here...said a voice. (99-100)

Another epitome of irreducible elements in the story is the central talisman with a hole in it. Miss Forcible and Miss Spink give it to Coraline before she begins her journey to the other world. They believe the stone "might help... They're good for bad things, sometimes" (24). Herein, some questions arise: how do the Misses own the stone? How do they know something bad may happen to Coraline? No answer, however, is given to such questions and once again the audience is made to accept these extraordinary matters to be a part of the real-life world. Miss Forcible and Miss Spink recall sorceresses and enchantresses in fantasy literature by literally soothsaying the upcoming events; they can "read the [tea] leaves... read... [the] future" (23) and tell the young protagonist that she will be "in terrible danger" (29). The Misses' 
predictions do not terminate here; in the last chapter, when Coraline triumphs over the beldam and returns home, the other mother's cut hand furtively chases after her. Coraline can discover its presence only after Miss Forcible and Miss Spink read her tea leaves for the second time: "everything is coming up roses... [except something that] looks almost like a hand" (180).

To create a more realistic effect, Gaiman sets these supernatural means in a realistic context. Concerning the technique of the matter-of-fact narration, Faris maintains that because realist fiction depicts a factual description of the normal workaday world, the readers of such books are acquainted with definable phenomena or "focalizations" (44); on the contrary, in magical realist fiction, the origin of the incidents is equivocal. To define the co-existence of two paradoxical perspectives towards these events, Faris coins the term "defocalization" (43). Authors like Gaiman benefit from the accurate depiction of the ordinary world illustrated in realistic fiction in order to lessen the effects of defocalized narration and consequently represent their stories as more real. In short, it is apparent that the inexplicable elements presented in Coraline are well incorporated into the real world, hardly inducing any commentary by the protagonist, "who model[s] such acceptance for...readers" (Faris 8).

Detailed description of supernatural circumstances and magic objects is the second quality of magical realism in Faris's list. According to her, meticulous description of the paranormal strengthens the existence of the phenomenal world. This method of narration is apparently "the realism in magical realism, distinguishing it from much fantasy and allegory" (Faris 14). Gaiman deftly represents this quality in Coraline's narration. One cogent example of such portrayal is the time when Miss Spink gives the magic stone to the young girl:

She got up from the armchair and went over to the fireplace. On the mantelpiece was a small jar, and Miss Spink took off the top of the jar and began to pull things out of it. There was a tiny china duck, a thimble, a strange little brass coin, two paper clips and a stone with a hole in it. (24)

Here, the supernatural is presented as a realistic phenomenon by placing a magical object among fripperies which can be found in any ordinary house.

Exploring magical realist elements to maintain "a middle ground between Marxism and postmodernist theory" in West African Fiction, Brenda Cooper 
explains that magical realist experts venture a third space that is a place for capturing "the paradox of the unity of opposites" (1). As such, it is possible to do so only by looking at the third zone afresh or, as she puts it, by "seeing [it] with a third eye" (1). Our study feasibly borrows from Cooper to claim that, as beldam's tricks are more than man's eye can meet, the magic stone acts as the third eye through which Coraline can find the hidden place of the captives. At the time of the interaction between the magical and the realistic, a third realm exists, a zone that is neither quite real nor magical. This place can thus be identified as the third space, which requires a third eye for gaining a true insight into the essence of this realm, hence the adventurer's need for an object like the magic stone to behold the preternatural. The stone with a hole in it acts like the telescope in E.T.A. Hoffmann's "The Sandman", through which Nathanael can recognize the strange bush. Such objects on which the protagonists depend to improve their vision are used to connect the characters with the preternatural world in the same way that the eyes act as "a link with the world" (Kayser 73).

Moreover, as the second quality in Faris's framework suggests, Gaiman creates a fictional world within and similar to the one Coraline herself lives in. In the description of the beldam's flat; every detail is concerned in order to induce the audience to believe in the magical events befallen Coraline. Once, the author pictures a real painting of a "bowl of fruits (a bunch of grapes, two plums, a peach and an apple) hanging on the wall" (86). The next time that he refers to the same painting, the fruit in it is said to have been "eaten, and all that remained in the bowl was the browning core of an apple, several plum and peach stones, and the stem of what had formerly been a bunch of grapes" (148). The description of one specific painting in two distinct scenes encourages the readers to inevitably accept the fruits are really eaten. These elaborate portrayals of the supernatural "weave a textual fabric that joins" the workaday world and the other mother's territory (Faris 91). As mentioned above, most often, the narration of the magical realist fiction creates a third zone or in Faris's terms, an "ineffable in-between" (46) space in which a sense of the enigmatic pervades the ordinary. This sense emerges not because of the presence of the supernatural events but for the reason that these incidents are described in detail and their extraordinariness may not thus bother the audience. However, they would make the readers hesitate to accept such realistic narration because they know "only the laws of nature" (Todorov 25).

The third fundamental characteristic of magical realism is unsettling 
doubts or what Todorov defines as the fantastic: "a dilemma: to believe or not to believe?" (83). Todorov asserts that the moment of hesitation may be experienced either by the readers, or by the character, or even by both (33). Defocalized narration in a magical realist story puts the readers in a dilemma as to the origin of the extraordinary events. It is then a critical matter to accept a preternatural phenomenon or totally reject it in such texts with many variations. In Coraline, the black feline's knowledge of the fact that the beldam is the creator of the other world disrupts the readers "normal sense of where such reports are coming from" (Faris 44). One moment of hesitation, moreover, would be when Mr. Bobo, an old man who lives in the attic and trains a mouse circus, tells Coraline "the mice have a message for you...The message is this. Don't go through the door" (25). At this point, the audience would be in a quandary whether to believe him or not. Can he really communicate with mice? If not, why does their warning make sense in later happenings? This sense of hesitation may becloud the supernatural elements and thus lead readers to consider the incident to be a production of the characters' imaginations, a hallucination or their daydreaming. Furthermore, Coraline once dreams of being "kidnapped by aliens" (30), and later she finds out that her parents "vanished under mysterious circumstances" (61). So, it is not inadmissible that the readers take the second case to be also a consequence of the protagonist's daydreaming. Even the other characters in the story cannot believe her. For instance, she calls the police "to report a crime ... kidnapping. Grown-up-napping really" (64); but her efforts to make them - and so the readers - take her seriously remain useless. Hence, she has to make herself ready to defeat the other mother in single combat. Therefore, her naïve or, better to say, her childish acceptance of the preternatural, while the other characters may be oblivious about the occurrences, is another motive for the readers to "hesitate about what attitude to take" (Faris 96). Even the explanation offered by the other father about the origin of the next-door world, that it "is all she made...the grounds, and the people in the house" (84), would not clarify the nature of the other mother herself. As a result, the doubts generated in the mind of the readers remain unresolved.

However, to present dreamlike circumstances in order to reinforce the realistic nature of magical phenomena is a feasible magical realist technique apt for children literature. To put it another way, this magical realist strategy initially cultivates the possibility of the supernatural as a dream or illusion and then repels that interpretation (Faris 18). After her parents are captured, Coraline sees them in the mirror. They stare at Coraline, and "her mother 
breathed on the inside of the mirror glass, and...wrote 'SU PLEH' with the tip of her finger" (63). The readers hesitate to take the scene as illusion or reality, and it seems the only way which may help them to decide on the matter and believe it as a real phenomenon, is a later moment when, for the second time, Coraline looks at the mirror:

In the mirror it was daytime...The door opened from the outside and Coraline's mother and father walked inside... 'That was a fine holiday,' said Coraline's father...The mirror fogged and faded and reflected the night once more...Coraline was sure in her heart that what she had seen in the mirror was no more than illusion. (73)

While the protagonist herself accepts one incident to be real and considers the other as a mere illusion, the readers, too, perforce have to believe what she believes in. As Faris puts it, the magical realist contingencies might be "dreamlike, and the text may both tempt us to co-opt them by categorizing them as dreams and forbid that co-option" (7). The alteration between reallife and dreams or imagination is a characteristic of the defocalized narrative in Coraline; but, to have dreamlike qualities does not categorize the story as a fantastic tale; rather, it is a magical realist tendency to impute some dreamlike quality to the text. Coraline's reactions to the happenings obviate the hostility between realism and the magical; therefore, the reader, who doubts the nature of the occurrences, accepts not to look for any elucidation. In such magical realist narratives, it is often typical to be in doubt, but this hesitation does not last long; otherwise, according to Todorov, the text falls into the realm of the fantastic:

In the universe evoked by the text, an event ú an action ú occurs which proceeds from the supernatural (or from the pseudo-supernatural); this action then provokes a reaction in the implicit reader (and generally in the hero of the story). It is this reaction which we describe as 'hesitation,' and the texts which generate it, as fantastic. (103)

So, as long as the audience is perplexed by the sight of the supernatural; the text still remains in the fantastic realm. Then, either a rational explanation is given to resolve this confusion and consequently the work is labelled as uncanny or, by employing a focalized form of narrative, the author persuades the readership to take the phenomenon as real. It is this latter technique from 
which Gaiman benefits to instil the marvellous/magical realist effects into his readers.

The conflation or near-merging of the phenomenal world and the primary one is the second to last characteristic of magical realism. The collapse of the worlds' boundaries endows the novel an ontological nature, a feature magical realism shares with postmodern fiction in general. In the present story, from the time the heroine discovers the walled door, a generic hybrid of the ordinary and the extraordinary pervades the atmosphere. What Gaiman portrays in this tale, is an apparent epitome of Brian McHale's description of postmodernist fiction:

A face-to-face confrontation between the possible (the 'real') and the impossible... Another world penetrates or encroaches upon our world...or some representative of our world penetrates an outpost of the other world, the world next door. (75)

The locked door Coraline finds in their house is the entrance to the nextdoor world. It can be gleaned from the above quotation that through the magical realist narration, Gaiman - similar to other postmodernists - razes the borderline between the factual and the supernatural worlds. Hence, not only does Coraline transgress the boundary, but the real black feline, the mice and the other mother also constantly interact with both worlds.

As indicated in the definition of the unsettling doubts, readers may hesitate to believe the penetration of the preternatural norms into the primary world and vice versa; however, some convincing evidence can be detected in the text that attests to the interaction of the magical and the realistic in the story and consequently causes the audience to admit the fusion of these two paradoxical realms. One possible justification that has already been touched on is the fact that Coraline can bring the magic stone - a pseudo-terrestrial object - to the other mother's flat and use it to find the souls of the children imprisoned in "the grey glass marble[s]" (115). Coraline's fictional world is indeed a doublesided reality with a two-lane highway; not only can she carry mundane things to the other world, but she is also capable of bringing other worldly objects to her real home. While trying to find the captives in the other world, Coraline injures her knee and feels "blood trickling down her ripped pyjama leg" (146). Returning to their own flat, she still has "cuts and scrapes" on her knee (168). The bricked door, thus, can be considered as an intersection of the magical (the beldam's flat) and the realistic (the Joneses' apartment). At a comparative 
level, children are presumably more attuned and subconsciously inclined to magical occasions and can find such incidents more plausible than adult readers, accepting them as part of reality.

According to Faris, the disruption of the conventional concepts of time, space and identity is the last key feature of magical realist fiction (23). Mysteriously, but parallel to the real world, the other mother's world seems to have existed for a long time. When Coraline opens the locked door for the first time, she has a dark corridor in front of her from which "a cold, musty smell [came, and]...it smelled like something very old and very slow" (33). She steps into an ancient place and is left puzzled as to whether the beldam created or found the place, to which the cat just divulges "either way, she had it a very long time" (90). The souls of the children, who speak in archaic words, have also been in the other mother's clutches for "so very long a time...time beyond reckoning" (100).

As has already been mentioned, the presence of a universe adjacent to the real one - even the existence of some uncharted realms from where a fairylike girl with "two wings - like dusty silver butterfly wings, not bird wings" (164) comes - reinforces Coraline to bear ontological weight. The existence of an abnormal character with wings is a known theme in magical realist texts. Such portrayal is recognizable in universally well-known magical realist works such as "An Old Man with Enormous Wings" (1955) by García Márquez and Night at the Circus (1984) by Angela Carter. Gaiman introduces this character type to reinforce the multidimensional nature of Coraline's world, a place where spirits, fairies, monsters and human beings live and interact with each other. There, as asserted by Todorov in relation to the phenomenal world, the demarcation between the variant realms are violated and "time and space....are not the time and space of everyday life... [, and ] ... time ... extends beyond what one imagines to be possible" (118). Therefore, the audience raises such questions as to what this world is, how it is created, and what happens when there is interplay between these different realms (McHale 10).

Moreover, the text reveals the fact that in an ontological collision of the realistic and the supernatural realms, the inhabitant of the primary world Coraline - struggles with the paranormal not only by keeping away the eerie invader - the other mother - but also by protecting her identity from being stolen by her. The reorientation of the regularities of place seems like it would be appropriate for developing the portrayal of a child in the quest for selfidentity. However, the quest Coraline has to undertake to the other world is different from her peer adventurers. This distinction lies in the Gothic-like 
ambience of the story, and Gaiman utilizes such elements "because gothicism helps [children] to initiate various stages of maturity in both a social and a sexual context" (Howarth iv).

The presence of horrific scenes is not a unique theme in the present novel; rather, it is one of the idiosyncrasies of Gaiman's writing style. The familiar touch of Gothicism and frightening elements appear from the very first scene of the story. The house to which the Joneses move is an old one with "an attic under the roof and a cellar under the ground and an overgrown garden with huge old trees in it" (3). The nights are haunted by the "black shapes" (20) and in daylight "the mist hung like blindness around the house... [and made it like a] ghost-world" (31). But, the most frightening aspect of the story is the existence of the other mother with black button eyes, spidery fingers and curved fingernails. Obviously, at one level of his description of the other mother, Gaiman depicts an image of the Gorgon sisters, ancient Greek female monsters similar to whom the other mother's "hair was wriggling like lazy snakes" (105). Akin to the Gorgons, there is something significant about her eyes: those who look at her are certainly frightened by her grim, soulless black button eyes. She threatens Coraline to trap her forever in the other world and steal her identity by replacing her eyes with black buttons as she has similarly preyed on other children, heretofore. However, Coraline has the chance of being warned by the souls of the beldam's victims about her intrigues:

She will take your life and all you are and all you care'st for, and she will leave you with nothing but mist and fog. She'll take your joy. And one day you'll awake and your heart and your soul will have gone. A husk you'll be, a wisp you'll be, and a thing no more than a dream on waking, or a memory of something forgotten. (101-102)

The motif of the extreme fear of being devoured, dominant in many other children's stories like "Little Red Riding Hood" and "Hansel and Gretel" (Watson 121), demonstrates the fact that children have the nightmare of a wolf, or other monsters like the other mother, waiting on the other side of the door to eat them. Coraline, too, is threatened to be eaten by the beldam (79), and thus in order not to succumb to the monster's threats, she avails herself of the magical agents; i.e., the stone with a hole in it, the talking black feline and the warning of the spirits. In spite of being in peril of losing her freedom to the other mother, she decides to return to the beldam's flat and fulfils her individualistic quest to extricate the captives from the beldam's clutches. As 
it is indicated, magical realist narratives disturb the conventional ideas about identity, which cause a fear of otherness to prevail in the story. The other mother alienates children from themselves by sewing black buttons in place of their eyes as barriers to see their souls (Vargas). Then, children are metamorphosed into a doll, an emotionless and identity-less object. Metamorphosis is another characteristic of a magical realist text; it is "a relatively common event" which embodies "in the realm of organisms a collision of two different worlds" (Faris, "Scheherazade's Children" 178). Children who are capitulated could not retain their past memories, their own selves or in other terms their identity. Coraline is also at the verge of losing her human identity, being alienated from her own self, changing into a doll with black button eyes, and ultimately a puppet in the hand of the beldam. She, however, strongly resists to be metamorphosed and battles against the other mother in her own clothes instead of wearing the clothes the beldam provides her, for they are a token of otherness. Wearing her own clothes, she feels more confident because she realizes who she is and how important it is to keep and establish her identity. Overall, the magic offered by the real people and their indirect help in her journey to the next-door world, empower Coraline to vanquish the beldam.

\section{Conclusion}

Coraline directly portrays many features which usually appertain to magical realist fiction. The storyline inserts its young readers into the protagonist's reallife world, where they encounter anthropomorphic animals, a mice circus, and an ageless female monster. Gaiman's Coraline plunges into the field of magical realism and creates an example of the genre in the realm of children's literature. Albeit the story moves to and fro the fantasy and is regarded by many as a fairy tale, the storyline reveals that the other mother's world is not a secondary one; rather, it is a part of the terrestrial realm. The presence of the magical features in a realistic setting adds to the credibility of the story. To reinforce it, Coraline benefits from the technique of matter-of-factness and describes inexplicable phenomena without providing any comments by the characters or the narrator. Looking from a magical realist perspective, the conflation of the magical world and the primary one has long been a convenient tool for a storyteller in creating a confrontation between reality and the supernatural in the process of discovering "what is mysterious in things, in life, in human acts" (Leal 121). By using this technique, Gaiman makes the frightening atmosphere of the 
novel more palpable to young readers, who are dispatched to Coraline's world to be acquainted with rough situations and become ready to deal with their problems. Coraline, thus, can be regarded as a typical example of children's magical realist stories the eerie scenes of which, in Coats's terms, help children to indirectly experience "circumstances that adequately represent for them the violent, bleeding cut that is psychically necessary for them to learn" in order to prepare them for mastering their fears and overcoming difficulties (91).

\section{Works Cited}

Coats, Karen. "Between Horror, Humour, and Hope: Neil Gaiman and the Psychic Work of the Gothic." The Gothic in Children's Literature: Haunting the Borders. Ed. Anna Jackson, Karen Coats, and Roderick McGillis. New York: Routledge, 2008. 77-92. Print.

Cooper, Brenda. Magical Realism in West African Fiction. London: Routledge, 2004. Print.

Faris, Wendy B. Ordinary Enchantments: Magical Realism and the Remystification of Narrative. Nashville: Vanderbilt University Press, 2004. Print.

--.. "Scheherazade's Children: Magical Realism and Postmodern Fiction." Magical Realism: Theory, History, Community. Ed. Lois Parkinson Zamora and Wendy B. Faris. London: Duke University Press, 1995. 163-9o. Print. Gaiman, Neil. Coraline. London: A\&C Black, 2009. Print.

Gooding, Richard. "Something Very Old and Very Slow': Coraline, Uncanniness, and Narrative Form." Children's Literature Association Quarterly 33.4 (2008): 390-407.

Howarth, Michael Robert. Under the Bed Creeping: A Psychoanalytic Approach to Gothicism in Children's Literature. Diss. University of Louisiana at Lafayette, 2007.

Kayser, Wolfgang. The Grotesque in Art and Literature. Trans. by Ulrich Weisstein. Bloomington: Indiana University Press, 1963. Print.

Leal, Luis. "Magical Realism in Spanish American Literature." Magical Realism: Theory, History, Community. Ed. Lois Parkinson Zamora and Wendy B. Faris. London: Duke University Press, 1995. 119-24. Print.

McHale, Brian. Postmodernist Fiction. London \& New York: Routledge, 1994. Print.

Parsons, Elizabeth, Kate McInally, and Naarah Sawers. "The Other Mother: Neil Gaiman's Postfeminist Fairytales." Children's Literature Association Quarterly 33.4 (Winter 2008): 371-389. Print. 
Rudd, David. "An eye for an I: Neil Gaiman's Coraline and Questions of Identity." Children's Literature in Education 39.3 (2008): 159-168. Print.

Vargas, José Roberto Saravia, and Juan Carlos Saravia Vargas. "A Girl in the Dark with Monsters: The Convergence of Gothic Elements and Children's Literature in Neil Gaiman's Coraline." Revista de Lenguas Modernas 21 (2014). Print.

Todorov, Tzvetan. The Fantastic: A Structural Approach to a Literary Genre. Translated by Richard Howard. Ithaca: Cornell University Press, 1975. Print.

Watson, Nancy. The Politics and Poetics of Irish Children's Literature. Dublin: Irish Academic Press, 2009. Print.

SAEEDE HOSSEINPOUR is a Graduate student in English Literature at Semnan University (Iran). Her area of interest is magical realism and children's literature, with regard to which her M.A. thesis focuses on fantasy and magical realism in the works of authors such as Lewis Carroll and Neil Gaiman.

Saeede.hosseinpour@semnan.ac.ir

NAHID SHAHBAZI MOGHADAM is an Assistant Professor in the Department of English Language and Literature, Semnan University (Iran). Her area of interest involves the fantastic and the grotesque, twentieth-century British fiction, comparative literary studies, and literary translation. She has published articles in these areas focusing on authors like Mervyn Peake and Ian McEwan, and her translations of Mervyn Peake's Boy in Darkness and Other Stories and Ernest Hemingway's The Snowes of Kilimanjaro into Persian have been published in recent years.

n.shahbazi@semnan.ac.ir 